\title{
Hypertrophic osteopathy associated with systemic granulomatous disease in a horse
}

\section{Osteopatia hipertrófica associada à doença granulomatosa sistêmica em um equino}

\author{
Liomara Andressa do Amaral Kwirant ${ }^{1 *}$; Flavio Desessards De La Côrte ${ }^{2}$; \\ Karin Erica Brass ${ }^{2}$; Cláudio Severo Lombardo Barros ${ }^{3}$; Ricardo Barbosa de Lucena \\ Maria Elisa Trost ${ }^{5}$; Rafael Costa Ebling ${ }^{6}$; Mariana Cocco $^{7}$
}

\begin{abstract}
A 4-year-old Criollo stallion was presented at the equine clinic of veterinary hospital of the Federal University of Santa Maria, RS, with a 30-day history of progressive weight loss, anemia and swelling of the forelimbs and face. Physical examination revealed that the swelling was firm and had a bone-like consistency, also radiographs showed extensive periosteal proliferation on the forelimb long bones that suggested hypertrophic osteopathy (Marie's disease). Physical examinations identified no respiratory findings. However, during ultrasound examination, superficial lung disease was identified. The animal was treated with antibiotics and nonsteroidal anti-inflammatory drugs for 12 days. Due to a complete lack of response to this treatment, the horse was euthanized. At necropsy several granulomatous lesions were identified in the thorax, abdomen and testicular tunics. Bony proliferation was evident on many bones of the appendicular skeleton and face. Based on these findings the diagnosis of hypertrophic osteopathy associated with sarcoidosis was established. It is important to perform a thorough clinical examination and include hypertrophic osteopathy in the differential diagnosis of diseases that are accompanied by swelling of the face and limbs as edema from various causes, fibrous osteodystrophy, for example.
\end{abstract}

Key words: Pulmonary. Periosteal. Sarcoidosis. Pathology.

\section{Resumo}

Um garanhão Crioulo, 4 anos de idade, foi atendido na clínica de equinos do hospital veterinário da Universidade Federal de Santa Maria, RS, com histórico de emagrecimento progressivo há 30 dias, anemia e aumento de volume dos membros torácicos e da face. $\mathrm{O}$ exame físico revelou que o

\footnotetext{
${ }^{1}$ Discente do Programa de Pós-Graduação em Medicina Animal, Equinos, Universidade Federal do Rio Grande do Sul, UFRGS, Porto Alegre, RS, Brasil. E-mail: liomara_amaral@hotmail.com

2 Profs. Associados, Dept ${ }^{\mathrm{o}}$ de Clínica de Grandes Animais, Universidade Federal de Santa Maria, UFSM, Santa Maria, RS, Brasil. E-mail: delacorte2005@yahoo.com.br; kbrass@terra.com.br

${ }^{3}$ Prof. Titular Aposentado, Dept ${ }^{\circ}$ de Patologia, Laboratório de Patologia Veterinária, UFSM, Santa Maria, RS, Brasil. E-mail: claudioslbarros@uol.com.br

${ }^{4}$ Prof. Efetivo, área de Patologia Veterinária, Universidade Federal da Paraíba, UFPB, Areia, PB, Brasil. E-mail: lucena.rb@gmail. com

${ }^{5}$ Prof ${ }^{a}$ Adjunto, curso de Medicina Veterinária, Universidade Federal do Pampa, UNIPAMPA, Uruguaiana, RS, Brasil. E-mail: m_elisa_trost@yahoo.com.br

${ }^{6}$ Discente do Programa de Residência em Área Profissional da Saúde, Medicina Veterinária, Dept ${ }^{\circ}$ de Clínica de Grandes Animais, UFSM, Santa Maria, RS, Brasil. E-mail: rafaelcostaebling@gmail.com

${ }^{7}$ Discente de Graduação do curso de Medicina Veterinária, UFSM, Santa Maria, RS, Brasil. E-mail: mariana.cocco@hotmail.com

* Author for correspondence
} 
aumento de volume era firme e apresentava consistência óssea. Radiografias também mostraram extensa proliferação periosteal nos ossos longos dos membros anteriores, o que sugeriu a osteopatia hipertrófica (doença de Marie). Os exames físicos não identificaram alteração respiratória. No entanto, durante o exame ultrassonográfico, foi identificada doença pulmonar superficial. O animal foi tratado com antibióticos e anti-inflamatórios não esteróides durante 12 dias. Devido a uma completa falta de resposta ao tratamento, o cavalo foi sacrificado. Durante a necropsia, várias lesões granulomatosas foram identificadas no tórax, abdômen e túnicas testiculares. Proliferação óssea era evidente em vários ossos do esqueleto apendicular e da face. Com base nestes resultados o diagnóstico de osteopatia hipertrófica associada à sarcoidose foi estabelecido. É importante realizar um exame clínico completo e incluir a osteopatia hipertrófica no diagnóstico diferencial de enfermidades que vêm acompanhadas de aumento de volume da face e dos membros como edema por diversas causas e osteodistrofia fibrosa, por exemplo.

Palavras-chave: Pulmonar. Periósteo. Sarcoidose. Patologia.

\section{Introduction}

Hypertrophic osteopathy (HO) is a symmetric bilateral progressive proliferation of subperiosteal bone substance and fibrous connective tissue of the appendicular and axial skeleton, and facial bones. The clinical suspicion of HO can be confirmed by radiographic identification of periosteal new bone formation involving the diaphyses and metaphyses of the appendicular and facial bones (KATZ, 2015). It is a relatively rare disease in horses. It occurs more frequently in man and dogs, usually associated with lung tumors (KAWCAK; BAXTER, 2011).

In horses, this syndrome has been associated with various diseases, especially thoracic injuries, such as lung abscesses, lung neoplasms, granulomatous pneumonia, rib fractures with pleural adhesions and pericarditis (CHAFFIN et al., 1990; MAIR et al., 1996; MAIR; TUCKER, 2004; BAYLESS et al., 2014). HO has also been described associated to gastric squamous cell carcinoma (SCHLEINING; VOSS, 2004).

Systemic granulomatous disease (SGD) is a rare condition that affects horses, characterized by noncaseous granulomatous inflammation of skin and/or multiple organs. Clinical signs vary depending on the organic system involved, but progressive weight loss, inappetence and fever are clinical findings frequently observed in horses with SGD (REES, 2004).
HO secondary to SGD was previously described in one horse in a retrospective study of 24 horses with HO. However, the horse recovered after prolonged treatment with corticosteroids, and there is no further information regarding the distribution of granulomatous lesions (MAIR et al., 1996). The present study describes a case of $\mathrm{HO}$ associated with systemic granulomatous disease in a horse.

\section{Case Report}

A 4-year-old Criollo stallion was referred with a one-month history of progressive weight loss accompanied by edema of the forelimbs and face (Figures 1A and 1B). Clinical examination, except for the high body temperature $\left(39.5^{\circ} \mathrm{C}\right)$, showed no changes (heart rate: 42 ; respiratory rate: 12; normal colored mucous). Palpation of the lower limbs showed hard swelling, pointing to the radiological evaluation of the limbs. Radiographs taken from both third metacarpal bones showed severe periosteal proliferation suggesting HO. Laboratory tests showed anemia (Ht 27\% / reference range: 32-53\%), leukocytosis (16,500 $\mu \mathrm{L}^{-1} /$ reference range: 5400-14,500 $\mu \mathrm{L}^{-}$ $\left.{ }^{1}\right)$ with neutrophilia $(73 \%)$, hyperproteinemia (8.8 $\mathrm{g} \mathrm{dL}^{-1} /$ reference range: 5.8-8.7 $\mathrm{g} \mathrm{dL}^{-1}$ ), hyperfibrinogenemia $\left(800 \mathrm{mg} \mathrm{dL}^{-1} /\right.$ reference range: $\left.100-400 \mathrm{mg} \mathrm{dL}^{-1}\right)$ and hypoalbuminemia $\left(1.3 \mathrm{~g} \mathrm{dL}^{-1}\right.$ / reference range: 2.6-3.7 $\mathrm{g} \mathrm{dL}^{-1}$ ). During thoracic 
ultrasonography bilateral presence of "comet tail" artifacts (suggestive of pleural lesion), most evident in the ventral portion of the lungs, was identified. Analysis of peritoneal fluid showed an increase in nucleated cells $\left(18,800 \mu \mathrm{L}^{-1}\right)$, predominantly neutrophils (96\%) and $3.4 \mathrm{~g} \mathrm{dL}^{-1}$ total protein. Treatment was started with sulfamethoxazole and trimethoprim (20mg $\mathrm{kg}^{-1}$ b.i.d.), ketoprofen (2.2mg $\mathrm{kg}^{-1}$ b.i.d.) and omeprazole ( $4 \mathrm{mg} \mathrm{kg}^{-1}$ s.i.d.) for six days. No clinical improvement occurred and the association trimethoprim sulfa was replaced by ampicillin sodium (10 $\mathrm{mg} \mathrm{kg}^{-1}$ t.i.d.) for six more days. On the $12^{\text {th }}$ day, laboratory tests showed progressive anemia (Ht 21\%), hyperfibrinogenemia (800 $\left.\mathrm{mg} \mathrm{dL}^{-1}\right)$ and hypoalbuminemia $\left(1,18 \mathrm{~g} \mathrm{dL}^{-1}\right)$. Due to a complete lack of response to treatment and a further deteriorating condition, euthanasia was recommended. Euthanasia was performed by licocaine intrathecal injection $(20 \mathrm{ml})$, with the horse under general anesthesia (ketamine $2.2 \mathrm{mg}$ $\mathrm{kg}^{-1}$ and xylazine $1.1 \mathrm{mg} \mathrm{kg}^{-1}$ ), according to the rules of the Federal Council of Veterinary Medicine.

Figure 1. A: Forelimbs swelling. B: Evident face swelling. C: Numerous granulomatous nodules in the lung pleura, with predominantly cranial-ventral distribution. D: Numerous granulomatous nodules in smallcolon (serous membrane).

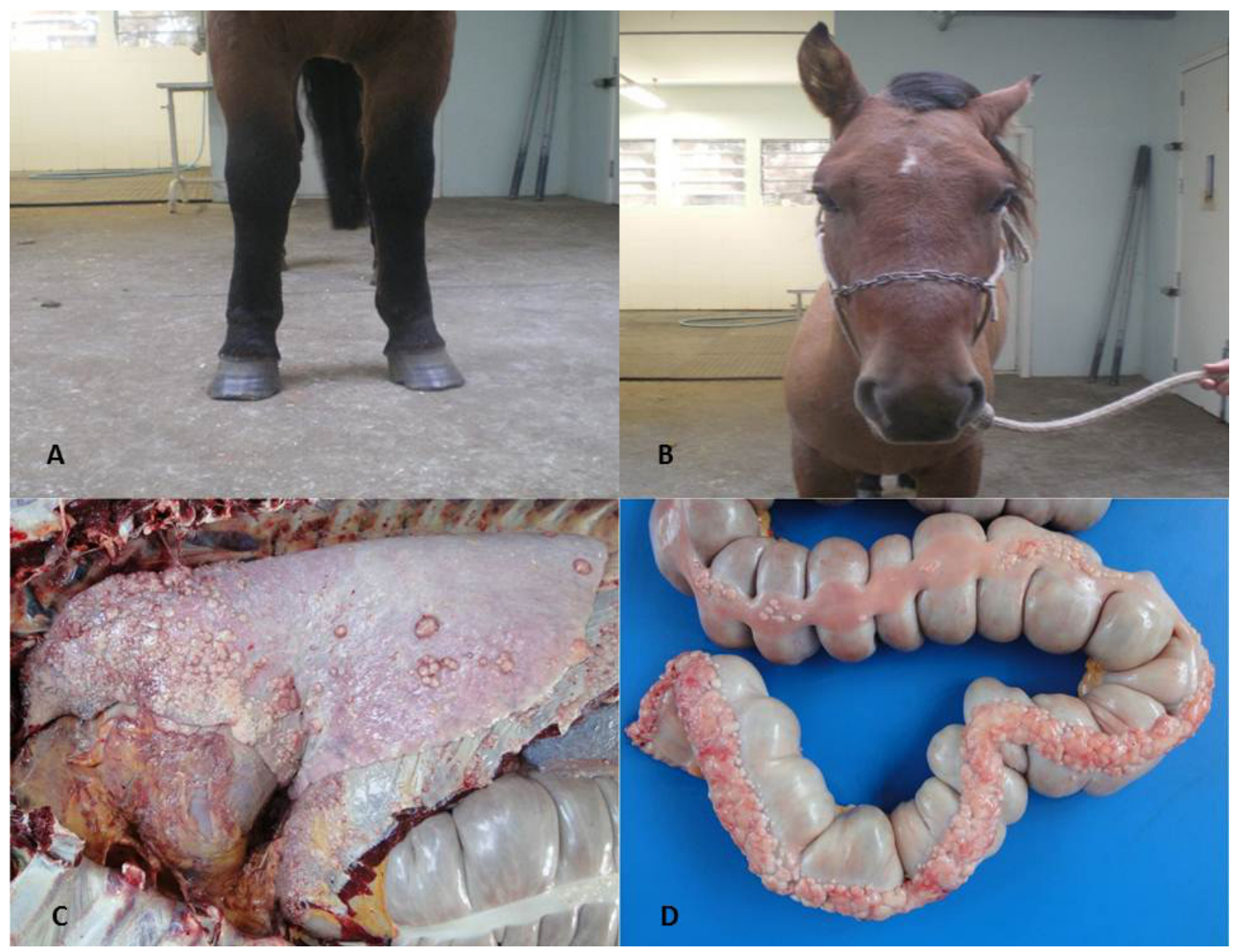

At necropsy, numerous small scabs on the skin of the limbs, ventral abdomen and scrotum were observed. Multiple white, firm, coalescing nodules with 0.5 to $1 \mathrm{~cm}$ in diameter were distributed on the pleura and in the lung parenchyma, predominantly in the cranio-ventral portions, compressing the underlying lung parenchyma (Figure 1C). Similar nodules were observed in 
the epicardium, myocardium. Multiple nodules were also observed in the mesenteric, hilar and tracheobronchial lymph nodes and on mesenteric, gastric, intestinal serous membrane (Figure 1D), spleen, diaphragma, liver and bladder wall, and infiltrating the testicular tunics. Fragments of all these organs, brain and bones were fixed in formalin, processed and stained with hematoxylin and eosin, Ziehl-Neelsen, Grocott, Giemsa, Masson's trichrome and by reaction with periodic acid-Schiff (PAS), by methods of routine. Nodules were sent for bacterial culture. Nodules were cultured both aerobically and anaerobically on 5\% sheep blood Agar. Fragments nodules were also cultured on Lowenstein-Jensen and Stonebrink Leslie solid culture medium, subsequently incubated at $37^{\circ} \mathrm{C}$ for up to 60 days (WAYNE; KUBICA, 1986).

After maceration of bones, it was observed periosteal new bone formation in the tarsal bones, metatarsus, tibia, carpus, metacarpus, radius and ulna, phalanges of pelvic and thoracic limbs, maxillary bone, mandible and nasal bones (Figures $2 \mathrm{~A}$ and $2 \mathrm{~B}$ ). There were no articular changes.

Figure 2. Macro and microscopic lesions of hypertrophic osteopathy. A: Osteoproliferative lesions in maxilar bone. B: Osteoproliferative lesions in a third metacarpal bone. The cortex throughout the length of the bone is covered by an irregular layer of fragile and porous bone spiculae. C: Non-caseating granuloma focally extensive on the lung. The center contains mainly Langhans giant cells (arrow) and numerous epithelioid macrophages, surrounded by lymphocytes and plasma cells. (Hematoxylin and eosin, 10x objective). D: Sub macroscopic image of a transversal section of radius. There is a continuous limit (arrow) between the cortical bone and the newly formed bone. (Hematoxylin and eosin, 4x objective).
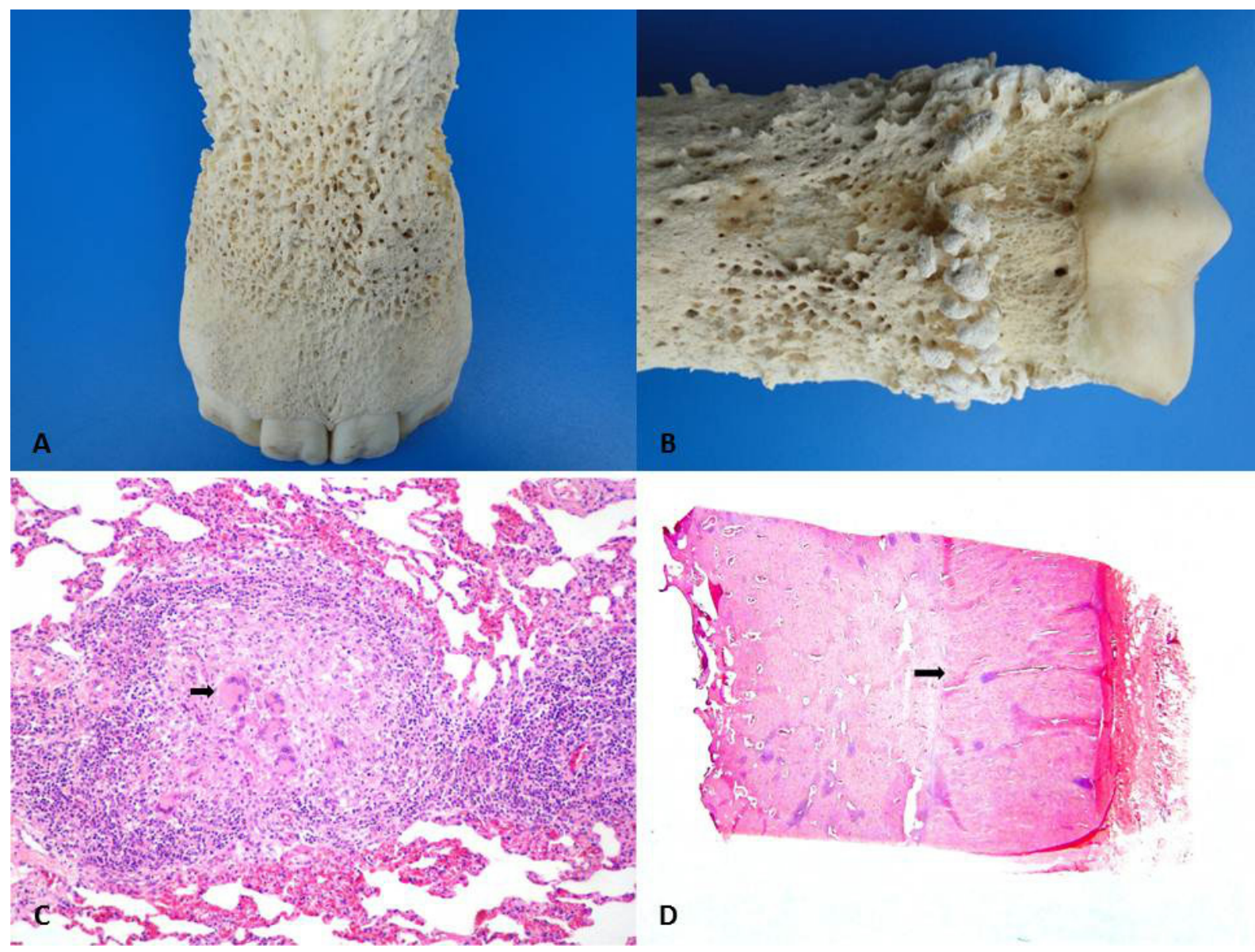
Histological evaluation of the lungs showed numerous coalescing nonencapsulated foci of nodular non-caseous granulomatous inflammation. Foci were composed of numerous epithelioid macrophages and multinucleated giant cells, mostly Langhans type. Surrounding these areas plasma cells and lymphocytes (Figure 2C) were observed. In areas adjacent to the granulomatous inflammation a marked proliferation of fibrous connective tissue made the pleura markedly thicker. Similar granulomas to those described in the lungs were also seen in the epicardium and myocardium, mesentery, mesenteric, tracheobronchial and hilar lymph nodes, liver, gastric serosa, small intestine, small colon, bladder and testicular tunics. There were no granulomas on the mucosal sections. Aggregates of epithelioid macrophages and giant cells were occasionally observed in the bone marrow. On the skin sections, variably circumscribed foci of lymphocytes, plasma cells, epithelioid macrophages and occasional giant cells were predominantly located in the superficial dermis. Histologically, the skeletal lesions consisted of periosteal bone trabeculae of irregular size and thickness that were arranged perpendicularly to the original bone cortex (Figure 2D). Masson's trichrome staining showed marked difference between cortical bone and new bone formation, as evidenced by the blue color of woven bone in recently proliferated bone tissue.

Histochemical evaluation (Ziehl-Neelsen, Grocott, Giemsa, Masson's trichrome and periodic acid-Schiff) of affected tissues did not detect the presence of infectious agents. There was no bacterial growth in aerobic and anaerobic cultures.

These findings corroborate with those observed by Mair et al. (1996), who described 24 cases of $\mathrm{HO}$ in horses. Of these, 9 had granulomatous inflammatory lesions at necropsy, and 14 had thoracic injuries, although extrathoracic lesions coexisted in some cases. Tomlinson et al. (2011) described a case of equine $\mathrm{HO}$ associated with nodular pulmonary fibrosis. In this case, the animal also had severe swelling of limbs, with progressive weight loss during six months with normal appetite and intermittent fever.

The HO pathophysiology is not well defined. The mechanism appears to involve an initial increase in blood flow to the limbs with consequent fluid retention, followed by proliferation of vascular connective tissue and periosteum and subsequent bone deposition. However, the initial events leading to increased blood flow are not known (TOMLINSON et al., 2011). Numerous theories have been proposed, including a hormonal and neurogenic cause. The hormonal disease refers to an increase in the estrogen level, which can be present in some cases. The neurogenic cause relies on the fact that vagotomy in humans can lead to regression of symptoms (KAWCAK; BAXTER, 2011). Chaffin et al. (1990) reported HO regression after treatment of an intrathoracic abscess in a horse. Enright et al. (2011) described HO regression in two animals treated with nonsteroidal antiinflammatories (NSAIDs) and corticosteroids. The horses had HO secondary to splenomegaly and inflammatory airway disease, respectively. In the present study, however, the injuries that led to hypertrophic osteopathy could only be identified during the necropsy and were characteristic of SGD.

SGD is also called equine sarcoidosis because of similarities with the systemic non-caseous granulomatous disease, sarcoidosis, which affects humans. However, it is preferable not to use this term to avoid confusion with the equine sarcoid. Like human sarcoidosis, SGD has no defined etiology. It is suggested that the disease results from an exaggerated immune response, against infectious agents or allergens that induce antigenic stimulus (REES, 2004). In horses, no agent was directly associated with SGD. All research using histochemical, immunohistochemical, microbiological culture and molecular tests were negative for etiologic agents (REES, 2004). The intake of vetch (Vicia villosa) was first incriminated as a cause of SGD in two horses, but later cases have been reported in horses that grazed in uncultivated 
areas without the plant (SPIEGEL et al., 2006). The horse of this report never grazed in a field planted with vetch.

The definitive diagnosis of SGD is made by exclusion of other agents and requires histopathological evaluation and immunohistochemistry. The main differential diagnoses include bacterial and fungal infections of the skin, poisoning, and neoplasms (REES, 2004; SPIEGEL et al., 2006). Where granulomatous disease appears to be limited to the skin the prognosis is good, as horses respond to treatment with corticosteroids. However, when there is systemic involvement, as in this case, the prognosis is poor. Horses with SGD usually are euthanized a few weeks or months after the onset of clinical signs.

It is important to perform a thorough clinical examination and include hypertrophic osteopathy in the differential diagnosis of diseases that are accompanied by swelling of the face and limbs as edema from various causes or fibrous osteodystrophy, for example.

\section{References}

BAYLESS, R.; ALMES, K.; CHOUDHARY, S.; BEARD, W.; GARCIA, E.; BILLER, D. Hypertrophic osteopathy in a three-year-old quarter horse mare. Israel Journal of Veterinary Medicine, Tel-Aviv, v. 69, n. 3, p. 151-156, 2014.

CHAFFIN, M. K.; RUOFF, W. W.; SCHMITZ, D. G.; CARTER, G. K.; MORRIS, E. L.; STEYN, P. Regression of hypertrophic osteopathy in a filly following successful management of an intrathoracic abscess. Equine Veterinary Journal, London, v. 22, n. 1, p. 62-65, 1990.
ENRIGHT, K.; TOBIN, E.; KATZ, L. M. A review of 14 cases of hypertrophic osteopathy (Marie's disease) in horses in the Republic of Ireland. Equine Veterinary Education, Newmarket, v. 23, n. 5, p. 224-230, 2011.

KATZ, L. M. Hypertrophic osteopathy. In: SPRAYBERRY, K. A.; ROBINSON, N. E. Robinson's current therapy in equine medicine. $7^{\text {th }}$ ed. St. Louis: Saunders Elsevier, 2015. p. 268-270.

KAWCAK, C.; BAXTER, G. M. Principles of musculoskeletal disease. In: BAXTER, G. M. Adams $\&$ Stashak's Lameness in horses. $6^{\text {th }}$ ed. Oxford: WileyBlackwell, 2011. p. 871-955.

MAIR, T. S.; DYSON, S. J.; FRASER, J. A.; EDWARDS, G. B.; HILlYER, M. H.; LOVE, S. Hypertrophic osteopathy (Marie's disease) in Equidae: a review of twenty-four cases. Equine Veterinary Journal, London, v. 28, n. 3, p. 256-262, 1996.

MAIR, T. S.; TUCKER, R. L. Hypertrophic osteopathy (Marie's disease) in horses. Equine Veterinary Journal, London, v. 16, n. 6, p. 308-311, 2004.

REES, C. A. Disorders of the skin. In: REED, S. M.; BAYLY, W. M.; SELLON, D. C. Equine Internal medicine. $2^{\text {th }}$ ed. St. Louis: Saunders Elsevier, 2004. p. 667-768.

SCHLEINING, J. A.; VOSS, E. D. Hypertrophic osteopathy secondary to gastric squamous cell carcinoma in a horse. Equine Veterinary Education, Newmarket, v. 16, n. 6, p. 304-307, 2004.

SPIEGEL, I. B.; WHITE, S. D.; FOLEY, J. E.; DRAZENOVICH, N. L.; IHRKE, P. J.; AFFOLTER, V. $\mathrm{K}$. A retrospective study of cutaneous equine sarcoidosis and its potential infectious aetiological agents. Veterinary Dermatology, Oxford, v. 17, n. 1, p. 51-62, 2006.

TOMLINSON, J. E.; DIVERS, T. J.; MCDONOUGH, S. P.; THOMPSON, M. S. Hypertrophic osteopathy secondary to nodular pulmonary fibrosis in a horse. Journal of Veterinary Internal Medicine, Lakewood, v. 25, n. 1, p. 153-157, 2011.

WAYNE, L. G.; KUBICA, G. P. The mycobacteria. In: SNEATH, P. H. A.; SHARPE, M. E.; HOLT, J. G. Bergey's manual of systematic bacteriology. $8^{\text {th }}$ ed. Baltimore: Willians e Wilkins, 1986. p. 1435-1457. 